\title{
Thermal Comfort in Living Room of Houses with Different Frontage
}

\author{
Ahmad Ridzwan Othman'1, Mohammad Ezzat Fakhrawi Mohammad Faisal' ${ }^{1}$, Wahyuni Zahrah² \\ 1 Faculty of Architecture, Planning and Surveying, Universiti Teknologi Mara, 43200 Puncak Alam, Selangor, Malaysia \\ 2 Department of Architecture, Faculty of Engineering, Universitas Sumatera Utara, Medan 20155, Indonesia
}

dwan_arc7@yahoo.com, ezzat.fakhrawi@gmail.com,Wahyuni.zahra@usu.ac.id

Tel: +60192241631

\begin{abstract}
House frontage is an essential aspect of terraced house design to ensure the occupant's comfort and healthy living. Four samples selected to evaluate the influence of the window to wall ratio (WWR) towards the internal thermal comfort of the house. The indoor thermal parameters were recorded using HOBOware Data Logger and evaluated using CBE Thermal Comfort Calculator. The study shows that the living room with a bigger WWR had the lowest thermal comfort levels. Besides the WWR, window placements and the shading devices also help in reducing the sun exposure of the frontage wall and increase the indoor thermal comfort.
\end{abstract}

Keywords: Frontage; Thermal Comfort; Window to Wall Ratio; Sun Exposure

eISSN: 2398-4287@ 2021. The Authors. Published for AMER ABRA cE-Bs by e-International Publishing House, Ltd., UK. This is an open access article under the CC BYNC-ND license (http://creativecommons.org/licenses/by-nc-nd/4.0). Peer-review under responsibility of AMER (Association of Malaysian Environment-Behaviour Researchers), ABRA (Association of Behavioural Researchers on Asians/Africans/Arabians) and cE-Bs (Centre for Environment-Behaviour Studies), Faculty of Architecture, Planning \& Surveying, Universiti Teknologi MARA, Malaysia.

DOI: https://doi.org/10.21834/ebpj.v6i16.2636

\subsection{Introduction}

In urban areas, due to the economic boom and rapid population growth, houses are always in demand. National Property Information Centre (NAPIC), (2018), revealed the statistics that the high-rise units $(351,000)$ and terraced houses $(342,000)$ made up almost $80 \%$ of the overall house demand in Malaysia. Sometimes it is also called link-house, either single or two-stories. Terraced houses offer the reliability of middle-range priced housings and a comfortable plot of land for the occupants to live. The living room serves as the leading multi-purpose space where many activities take place. Usually, it is where occupants are taking rest, entertaining guests, watching television, and sometimes even having some refreshments. The living room acts as the main gateway from the car porch to other spaces in a house. As it is the most useable space where the occupants spend most of their time there, the layout should be efficient, and the indoor environment should be favourable and comfortable.

\subsection{Problem statement}

Terraced houses can come in many designs and sizes. Bigger frontage houses are preferred for they provide a better floor plan layout, which contributed to better daylighting design and offers better views through wider window openings. However, more extensive frontage houses not necessarily can provide excellent indoor thermal comfort. Many factors influenced the indoor thermal comfort, such as the size and the design of the window openings, the building material used, ventilation system, building orientation, and shading devices.

eISSN: 2398-4287C 2021. The Authors. Published for AMER ABRA cE-Bs by e-International Publishing House, Ltd., UK. This is an open access article under the CC BYNC-ND license (http://creativecommons.org/licenses/by-nc-nd/4.0/). Peer-review under responsibility of AMER (Association of Malaysian Environment-Behaviour Researchers), ABRA (Association of Behavioural Researchers on Asians/Africans/Arabians) and cE-Bs (Centre for Environment-Behaviour Studies), Faculty of Architecture, Planning \& Surveying, Universiti Teknologi MARA, Malaysia.

DOI: https://doi.org/10.21834/ebpj.v6i16.2636 
Discussing terraced houses of different frontage, one cannot merely judge on the physical dimension that a more extensive frontage will have better natural ventilation (assuming more windows available). The window design, the size, the placement, and the operation type (fixed or adjustable) are factors that need consideration before making any deduction. It is good to note that a more significant frontage could also mean a bigger wall surface being exposed to the sun, hence, causes a more significant thermal heat gain. Pathirana et al., (2019) in their study found that there was a positive correlation between WWR and discomfort hours. WWR of 20 gives the best thermal comfort (minimum discomfort hours).

\subsection{Research aim and objectives}

This study aims to do a comparative analysis of indoor thermal comfort in the living area of terraced houses of different frontage. In line with the aim, the objectives of the study are as follow:

- To determine thermal comfort levels experienced by the occupants in respective living area of the terraced houses of different frontage.

- To establish the passive strategies implemented into the design to enhance thermal comfort.

\subsection{Significance of the study}

The outcome of the study will provide a better understanding among the architects/designers to design a more conducive terraced house. They should not merely focus on the aesthetics but to address indoor thermal comfort as well. The developers also have better knowledge of what the potential house owners'/buyers' preferences, by providing a quality lifestyle, comfortable and healthy living. This study also promotes passive architecture, thus reducing the negative environmental impacts globally.

\subsection{Scope of the research}

The study covers the thermal comfort of occupants in the living area of a typical intermediate terraced house. Few samples selected within Klang Valley, which should represent other terraced houses in Malaysia. The correlation between the house frontage, WWR and other environmental parameters to the thermal comfort in the living room will be discussed and analysed. Does the WWR affect the thermal comfort of the occupants? However, only the thermal comfort in the living room will be studied and hoped it will represent other spaces in the house.

\subsection{Limitations of the study}

All the samples chosen are of similar characteristics, even though at a different location. The terraced houses are intermediate doublestories houses with first-floor overhang veranda. The frontage of the houses is facing north with a pitched roof. The material of the house is a brick wall with a plaster finish on both sides. The living room of each house is at the entrance of the frontage wall. These actions are essential to ensure minimum data variation between samples so that the results will be significant.

\subsection{Literature review}

\subsection{Terraced housing in Malaysia}

A market report shows that terraced residential houses were approximately 58\% of the country's housing stock in 2003 (Kubota et al., 2006) and more than $52 \%$ of them were single story. A report by the National Property Information Centre (NAPIC) in 2008 stated that most of the housing developments offered in the local residential market were 1 to 3 stories terraced houses. In the third quarter of 2008, from the total $4,158,232$ units of housing completed, 876,948 units were terraced houses, i.e., about $21 \%$ of the local residential properties market.

\subsubsection{Typical terraced house layout}
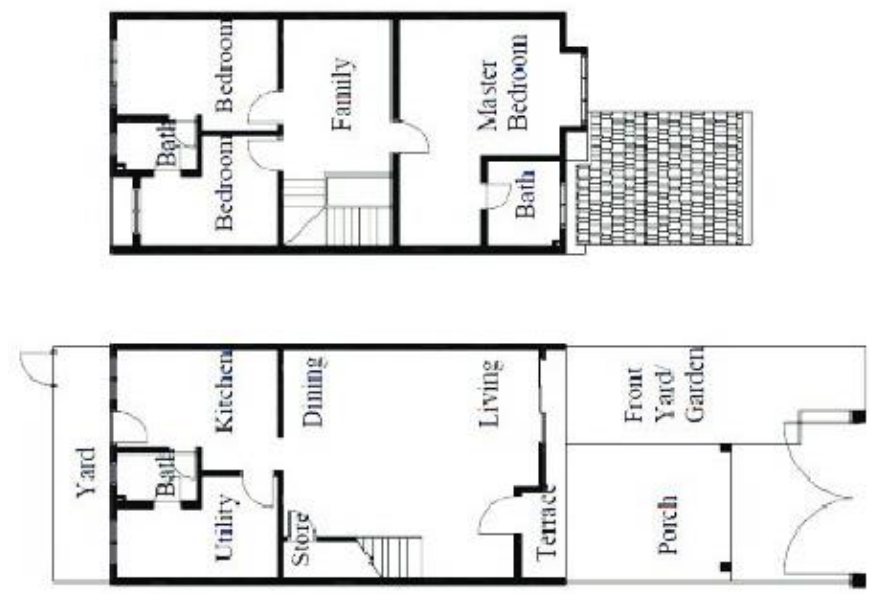

Fig. 1: A typical terraced house floor plan

(source: https://www.researchgate.net/figure/Typical-floor-plan-of-an-intermediate-unit-of-a-terrace-house-in-Malaysia ) 


\subsection{Thermal comfort}

In the city housing environment, optimum indoor comfort levels are essential for the recommended interior environment and healthy living. The common factors that influenced indoor comfort level are air movement, outdoor and indoor temperatures, openings, building materials and human activities, including the body itself (Thomas and Garnham, 2007). Rapid urbanization in the country has produced full attention that affects the environmental situation. It affects the exterior and interior comfort, energy consumed (heating and cooling of the building), and air pollutants. Usually, in urban areas, the air temperatures are slightly higher than the surrounding, mostly during the night. As a result, the interior air temperature will be relatively higher than the exterior air temperature. Without the mechanical system, the indoor airflow is insufficient, and the high indoor temperature will cause discomfort and affect the occupant's health condition (Zr \& Mochtar, 2013). Department of Standards Malaysia in 2017 has produced a guideline of a recommended indoor environment design for the country, which recommends the indoor temperature between $22^{\circ} \mathrm{C}-25^{\circ} \mathrm{C}$. Internal space conditions depend on many factors, including mean radiant temperature, relative humidity, air temperatures, and air velocity. Other studies on the comfortable air temperature found that it is relatively higher compares to other regions because of humans' ability to adapt to the internal temperature (Liping \& Hein, 2007). Zain, et al., (2007) in their study found that the thermal comfort may be achieved below $28.69^{\circ} \mathrm{C}$.

\subsection{Passive Design}

Longer sun exposure hours and poor ventilation strategies may cause lower thermal comfort in terraced houses with low WWR (Nugroho et al., 2007). The study found that for a terraced house of 7 meters wide and 20 meters long, the inside air temperature was below $31^{\circ} \mathrm{C}$ when the outside maximum air temperature was about $32^{\circ} \mathrm{C}$. The PMV distribution at the height of $1.1 \mathrm{~m}$ in the master bedroom illustrates that during the afternoon hours, the inside predicted mean vote (PMV) is noticeably lower (+0.5) than at noon (+2). The PMV was slightly warm (between +1 to +2 ) in the morning and changed to warm at noon $(+2.0)$ when the outside temperature became high. In the afternoon, the value was +0.5 , which showed as a near-neutral thermal comfort condition. The highest temperature difference in $\mathrm{KL}$ (Jamaludin et al., 2014) at $4.4^{\circ} \mathrm{C}$. Findings suggest that the highest indoor temperature of $32.6^{\circ} \mathrm{C}$ was recorded in a Master Bedroom under Kuala Lumpur climate at 1400 hours when the outside maximum air temperature was $37.0^{\circ} \mathrm{C}$.

During the designing stage of terraced houses, few important aspects to consider towards enhancing the occupants' comfort. The orientation of the frontage walls, the u-value of the building materials, WWR and the overall space arrangements for efficient air movement. The designer should minimize openings on the house frontage that facing the west or the east due to the long sun exposure hours and high heat intensity.

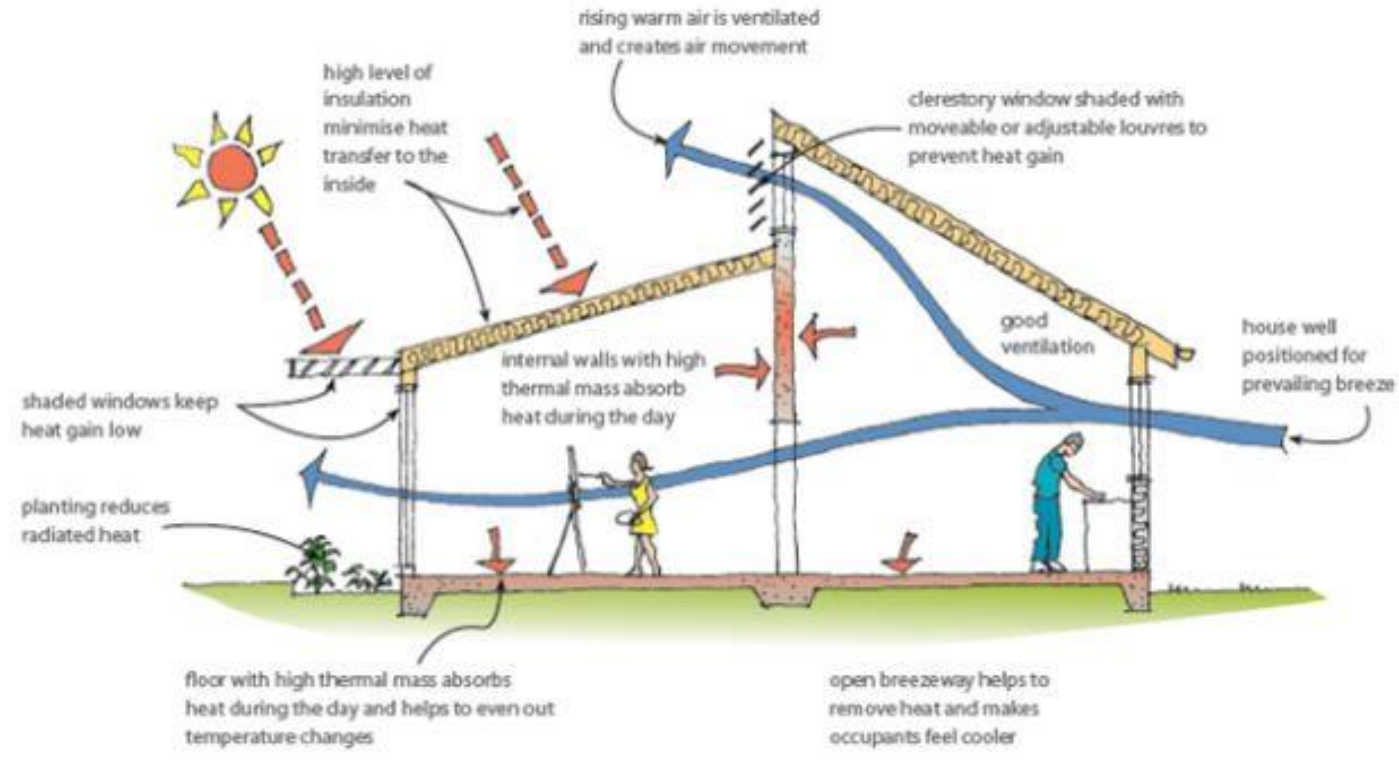

Fig. 2: Conceptual heat distribution inside a typical house (source: https://www.energy.gov/energysaver/design/energy-efficient-home-design)

\subsubsection{Orientation}

The orientation of a building is an essential aspect in a "passive" design approach. Understanding the sun orientation and availability of wind flow and its velocity will offer better house design that provides comfortable living and energy efficiency (Thomas and Garnham, 2007). Optimal design orientation affects the thermal comfort of occupants inside the house. Whenever the windows on the wall facing the east or west (experiencing longer sun exposure hours), shading devices are required. The idea is to minimize the penetration of the sun into the building during the daytime. Glare and direct solar radiation usually caused visual and thermal discomfort to the occupants. It can be reduced and controlled using horizontal shades and overhangs. La Roche et al. (2001) stated that in the Equatorial region, building design should avoid huge fenestration on the east and west, which receives approximately double the amount of solar and heat radiation compared to the north sides and south sides. 


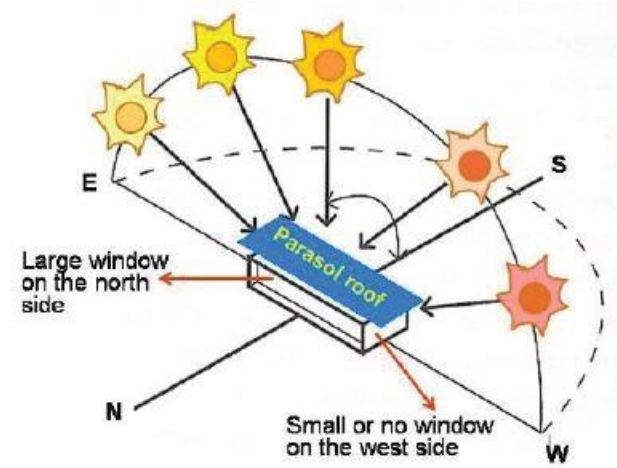

Fig. 3: The optimal orientation of the house in the equatorial region (source: https://energyeducation.ca/encyclopedia/Solar_panel_orientation)

\subsubsection{Air temperature}

The high fluctuation of heat can harm many factors such as necessary functions of enzymes not working at the optimum level of daily temperature limits. Maintaining proper balance requires the body to use many processes such as exhaling and inhaling air, producing sweat and blood circulation near the skin's surface to release heat. The involuntary reactions help the body to naturally cool off the heat produced during the movements of the joints that produce frictions. The heat produced was emitted from the body through the skin.

Earlier researchers established that humans perform optimally at temperature around $20^{\circ} \mathrm{C}$. However, Wyon (1969) in his study found that adolescent children have no problem to perform multitasking activities at the temperature of $27^{\circ} \mathrm{C}-30^{\circ} \mathrm{C}$. This study shows that air temperature does influence the human's performance rate, when the surrounding temperature getting higher, they started to feel uncomfortable, and so does their performance. In places where the natural ventilation is difficult to get or insufficient, mechanical systems are introduced to ensure effective ventilation system in the premise. Efficient air movement not only providing healthy fresh air but also helps in regulating the indoor air movement and indirectly lowering down the indoor air temperature.

\subsubsection{Relative humidity}

Humidity is the value of water vapor recorded in the surrounding environment. Higher humidity can cause precipitation and water droplets on the wall, openings such as windows and ceilings. This factor is one of the primary keys to maintaining the thermal comfort of the occupants.

\subsubsection{Wind movement}

Using Bernoulli's principle, the wind effect was used to extract the hot air within the house, especially the house with low roof gradient (slope). The pressure difference induced this phenomenon as the windward wall acquires positive pressure due to the incoming wind velocity, and the leeward wall experiences negative pressure, which results in suction. Low slope roof experience suction at the roof (Baskaran, 2002). The wind is directed to enter the windward and escapes the leeward wall. The roof structure experiencing the most suction compared to other parts of the building. The amount of suction generated on the roof depends on few factors such as the direction and speed of the wind, air turbulence and the geometry of the building. The airflow from the windward wall through to the leeward wall helps in extracting the heat through the leeward vent openings (US Department of Energy, 2011). The ventilated roof concept has been studied by many researchers and agreed that it helps to reduce the indoor temperature (Abdul Rahman et al., 2009).

\subsubsection{U-Value of material}

U-Value is a measurement of the heat transfer via a building component (such as a wall or openings) or the thickness of the desired material (insulators). Smaller number indicating it has a better insulation property. Heat transfer rate through a material (which can be a single or a composite) also influenced by the temperature difference across the building. The measurement unit for heat transfer is $\mathrm{W} / \mathrm{m}^{2} \mathrm{~K}$. As the building is highly insulated, it lowers the U-value of the component. The thermal transmittance will be higher if the insulation is poorly fitted.

Table 1: U-Value of materials for residential housing in Malaysia

\begin{tabular}{|c|c|c|c|c|}
\hline \multicolumn{3}{|c|}{ Material description } & \multirow{2}{*}{$\frac{U \text {-Value }\left(\mathrm{W} / \mathrm{m}^{2} \mathrm{~K}\right)}{2.9}$} & \multirow{2}{*}{$\frac{\text { Admittance }\left(\mathrm{W} / \mathrm{m}^{2} \mathrm{~K}\right)}{5.21}$} \\
\hline 1 & Floor & $100 \mathrm{~mm}$ thick suspended concrete floor plus ceramic tiles and plaster ceiling underneath. & & \\
\hline \multirow[t]{3}{*}{2} & Wall & & & \\
\hline & Internal & $100 \mathrm{~mm}$ brick with $10 \mathrm{~mm}$ plaster either side. & 2.72 & 4.32 \\
\hline & External & $130 \mathrm{~mm}$ brick with $10 \mathrm{~mm}$ plaster either side. & 2.44 & 4.46 \\
\hline 3 & Roof & $16 \mathrm{~mm}$ thick zinc metal deck roof with $150 \mathrm{~mm}$ air gap and $50 \mathrm{~mm}$ thick glass fibre insulation & 0.13 & 1 \\
\hline 4 & Ceiling & $10 \mathrm{~mm}$ suspended plaster board ceiling, plus $50 \mathrm{~mm}$ insulation, with remainder $(150 \mathrm{~mm})$ joists as air gap. & 0.5 & 0.9 \\
\hline 5 & Door & $40 \mathrm{~mm}$ thick hollow core plywood door. & 2.98 & 0.65 \\
\hline 6 & Window & Single pane of glass with aluminums frame & 5 & 5 \\
\hline
\end{tabular}




\subsubsection{Wind direction}

The global wind pattern occurs due to the earth spinning on its axis round the orbit. The wind velocity developed when there exists high pressure and low pressure at two different locations in Northern and Southern Hemisphere. This prevailing wind will change direction when it reached the Equator. The amount of moisture and precipitation is also affected by this phenomenon. The wind that blows from the ocean moves it from high pressure to lower pressure that allows the coast to receive rain. These winds are cold at night during the hot season. Based on latitudes, it moves in a globe, as the sun direction and earth's orbit. Selangor experiences the Northeast Monsoon from November to March, which is the rainy season, whilst from June to September experiencing the Southwest Monsoon which is the dry season.

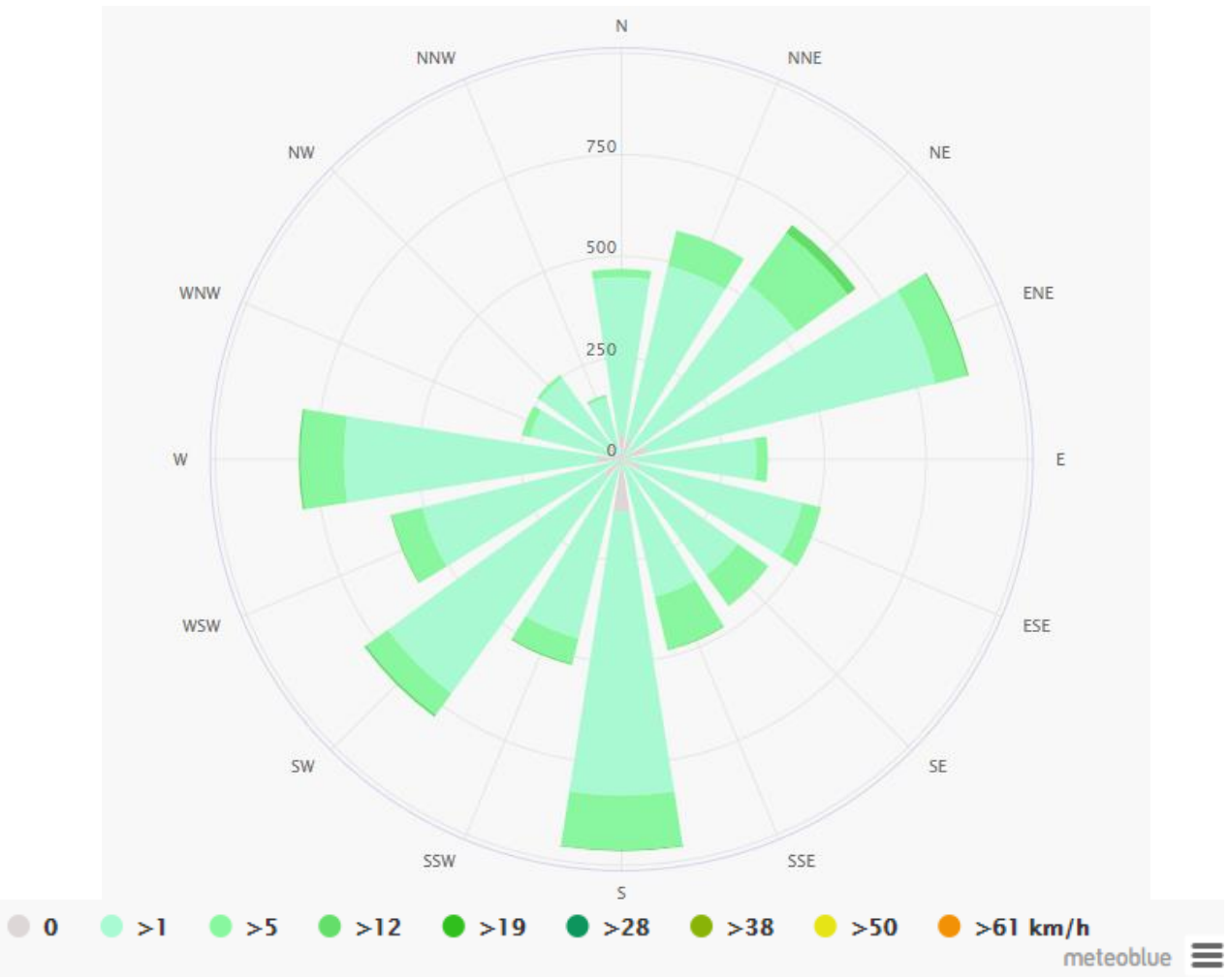

Fig. 4: Wind rose for Puncak Alam, Selangor

(source: https://www.meteoblue.com/en/weather/historyclimate/climatemodelled/puncak-alam_malaysia_1732903)

\subsection{Methodology}

Prior to the fieldwork survey, secondary data such as essential terminologies, related theories, and fundamental parametric data were gathered through journals, books, and websites. Primary data collected through field measurement, interviews, and questionnaires. This study conducted using a quantitative method, and data collected at two (2) terraced houses in Seksyen 6 Kota Damansara, Petaling Jaya, and two (2) terraced houses in Fasa 3, Puncak Alam.

\subsection{Data collection}

Data collections were through observation, physical measurement, and environment parametric data recordings using scientific instruments. Questionnaires distributed among the selected samples to gauge their thermal comfort level in the living room. Interviews with the selected occupants to gather feedbacks and opinions on any special aspects to consider for better house design and comfortable living.

\subsection{Study samples}

Two selected locations chosen as case studies, one in Kota Damansara and the other in Puncak Alam. Both located in Klang Valley, hence, not much variation among them in terms of climate and other influencing factors. The criteria in selecting a case study site were:

- Type of terraced house.

- The dimension of the frontage wall and the building material used.

- Size and position of openings such as windows and doors on the wall.

- The orientation of the houses

The study was at two (2) intermediate double-stories terraced houses in Seksyen 6 Kota Damansara, Selangor, and two (2) intermediate double-stories terraced houses in Fasa 3 Puncak Alam, Selangor. The air temperature, air velocity, and humidity were measured inside the living room to create a statistical data. 


\subsection{Procedure}

\subsubsection{Get permission and set an appointment}

Firstly, identifying suitable house types for the study. Two (2) double-stories terraced houses selected for this study, located in Puncak Alam. Both are of the same era (age) but of different frontage. House A with 20 feet width frontage and House B with 24 feet width frontage. To ensure a better comparative study, another set of terrace houses at another location was selected. The location chosen is at Kota Damansara, not far from the Puncak Alam (the first location) to ensure not much variation between the two sites with respects to climate. All the house samples having the ceiling height of 9 feet. Before the survey, a formal application to respective house owners made and permissions secured. Suitable dates selected and agreed upon with the respective house occupants for data collections.

\subsubsection{Fieldwork and physical measurements}

Houses where the floor plans not available, the layout and dimensions of the living room and the frontage wall were measured using tapes and range finder. The number of windows and their position determined, and the WWR calculated. To determine the overall heat transfer value across the frontage wall, the building materials used, and U-value were important. Interviews and questionnaires carried out to get feedback on the occupants' satisfaction levels with regards to thermal comfort.

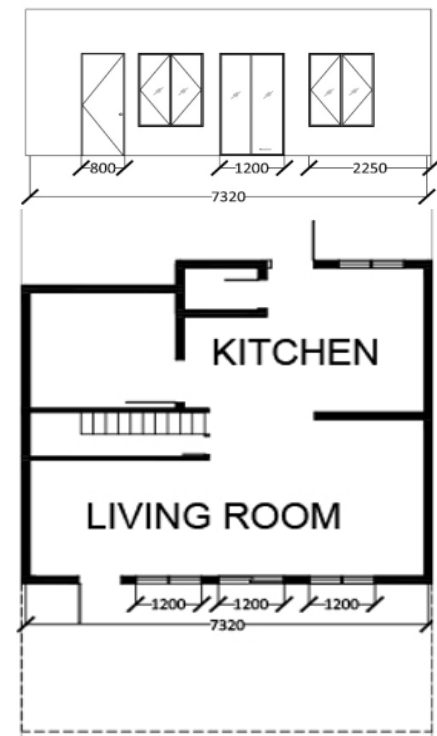

Ground Floor of House A
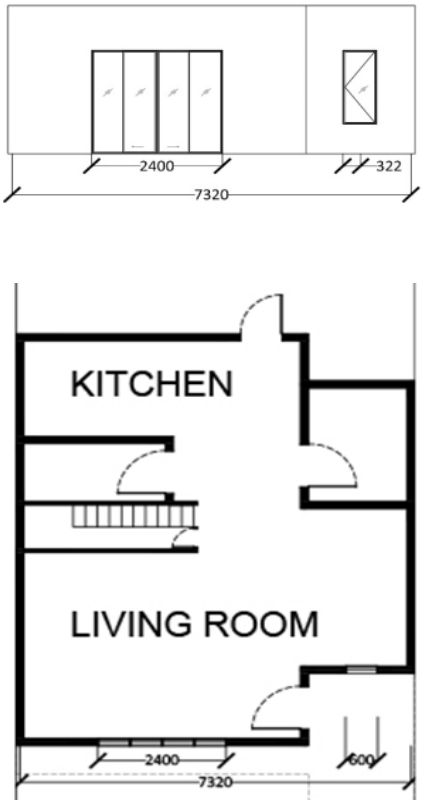

Ground Floor of House C
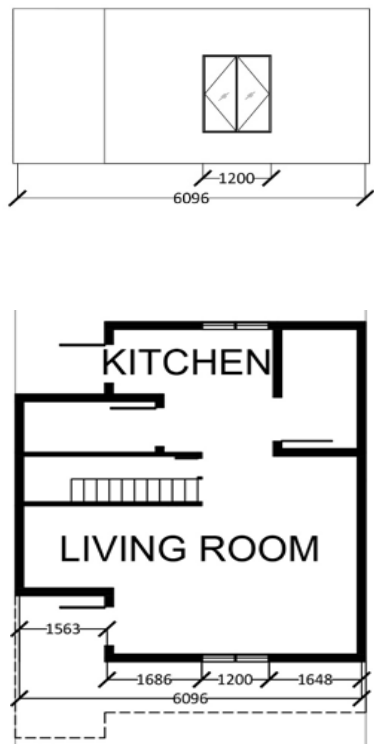

Ground Floor of House B

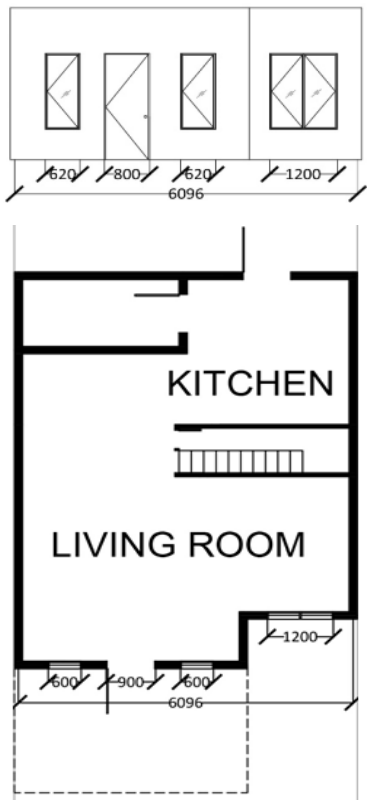

Ground Floor of House D

Fig. 5: Ground Floor Plans and the Façades of the four (4) house samples 


\subsubsection{Parametric data measurement}

Air temperature, indoor air velocity, and humidity were recorded in the living room using a thermal monitoring tool (HOBO Data Logger). The data loggers fixed on the wall at $1900 \mathrm{~mm}-2100 \mathrm{~mm}$ high. To ensure that all data gathered at all house samples were consistent, the outdoor climate condition on the respective survey day also recorded. The outdoor air temperature was measured using a digital thermometer and the outdoor velocity measured using an anemometer. Both outdoor and indoor air temperature necessary to obtain mean radiant temperature. Data collection at all venues (on different dates) were done at 10:00, 13:00, and 16:00 and analyzed using HOBOware software. The recorded data compiled and tabulated for analysis and deductions.

Data obtained was compared with the ANSI/ASHRAE Standard 55 to determine relative thermal comfort for the occupants at the four (4) selected houses.

\subsection{Results}

Fig. 6 shows that the thermal comfort zone does not comply with ASHRAE Standard 55, which resulted in lower thermal comfort for the occupants in house A. The Predicted Mean Vote (PMV) recorded as 1.03 which is over the recommended limits (>+0.5) with $27 \%$ of Predicted Percentage of Dissatisfied (PPD) which is the highest among the four selected houses. The occupants of the house felt a slightly warm sensation in the living room, hence, lowers the thermal comfort of the occupants. The Standard Effective Temperature (SET) is the highest at House $A$ at $28.9^{\circ} \mathrm{C}$, with the cooling effect of $4.0^{\circ} \mathrm{C}$. This indicated that it has the lowest cooling effect compared to the other three houses. Moreover, the Dry Bulb Temperature (DBT) at still air is the highest at $28.0^{\circ} \mathrm{C}$, and this shows that the house occupants experiencing the least comfortable situation.

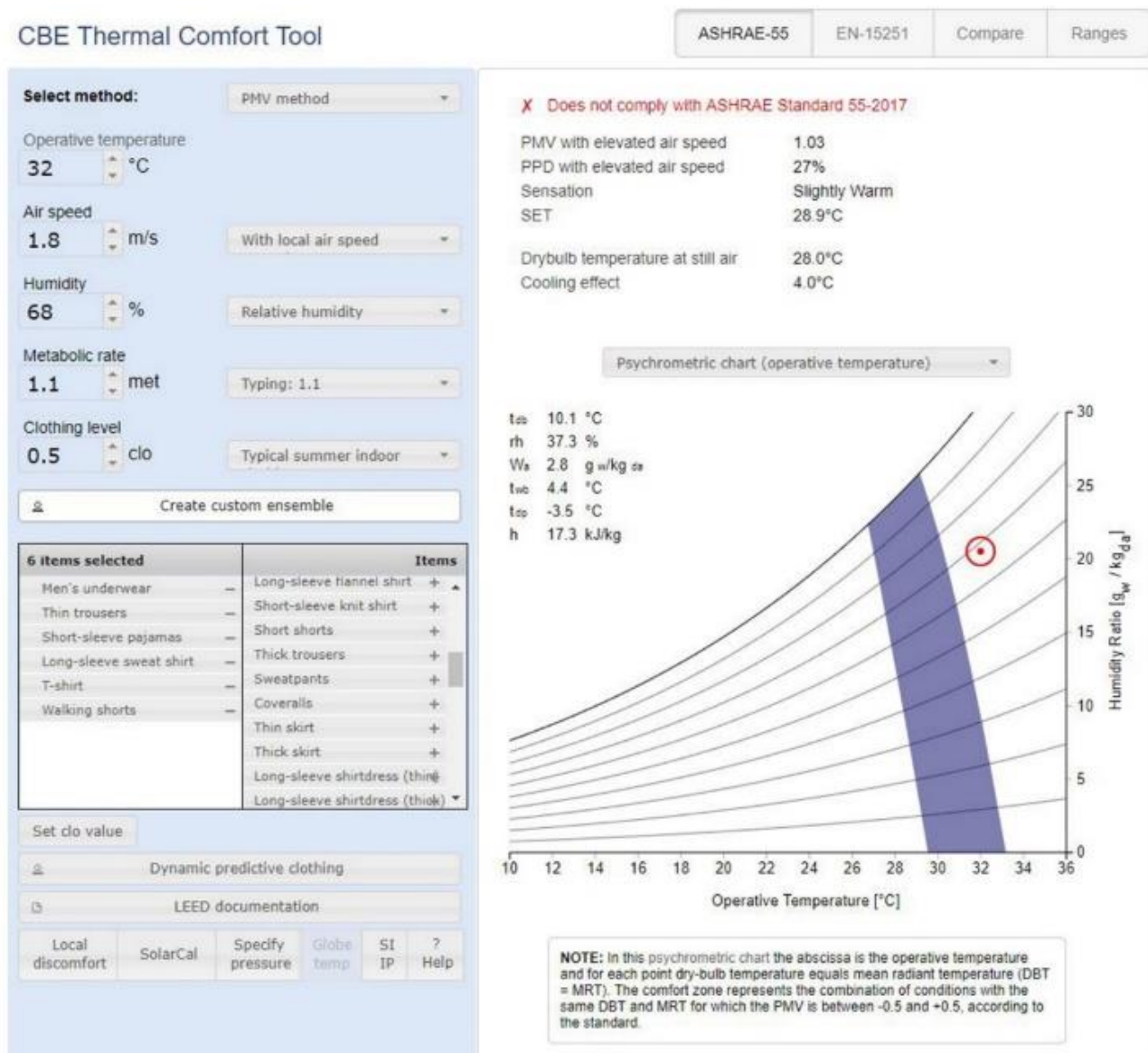

Fig. 6: Relative Thermal Comfort of Occupants in House A

Based on Fig. 7, House B complies with ASHRAE Standard 55. It shows that the occupants inside the house feel comfortable living inside the living room. The Predicted Mean Vote (PMV) complies with the standard $(<+0.5)$ at 0.45 . The Predicted Percentage of Dissatisfied is the lowest at $9 \%$ of the vote. Moreover, the occupants in the living room experience a neutral sensation, which resulted in a more comfortable living condition. The Standard Effective Temperature (SET) is the lowest at $26.6^{\circ} \mathrm{C}$, and the cooling effect is higher than house A which is at $4.3^{\circ} \mathrm{C}$. Furthermore, the Dry Bulb Temperature (DBT) recorded the lowest value at $26.6^{\circ} \mathrm{C}$. These factors induced a better thermal comfort zone for the occupants inside the living room. 

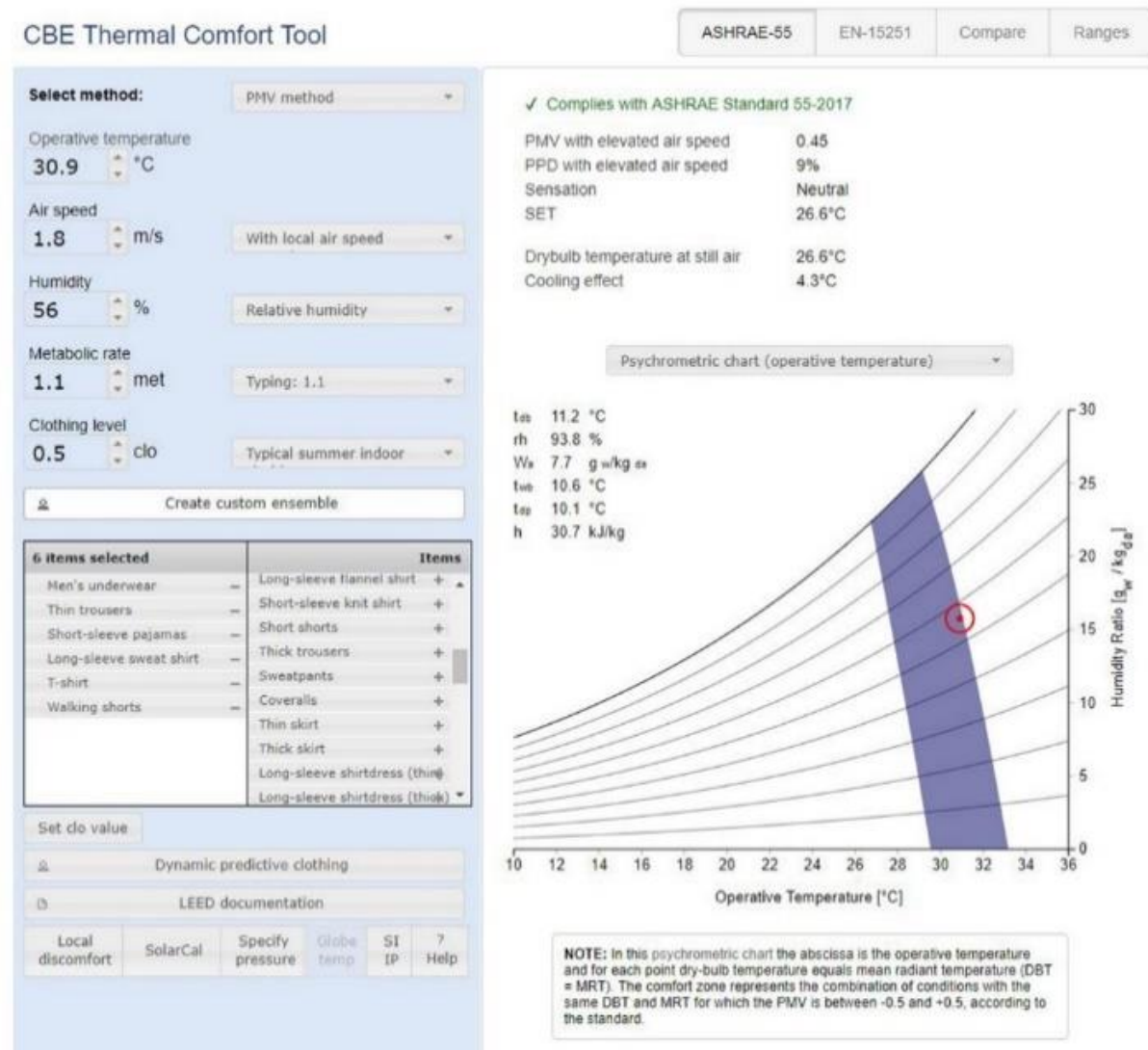

Fig. 7: Relative Thermal Comfort of Occupants in House B

CBE Thermal Comfort Tool

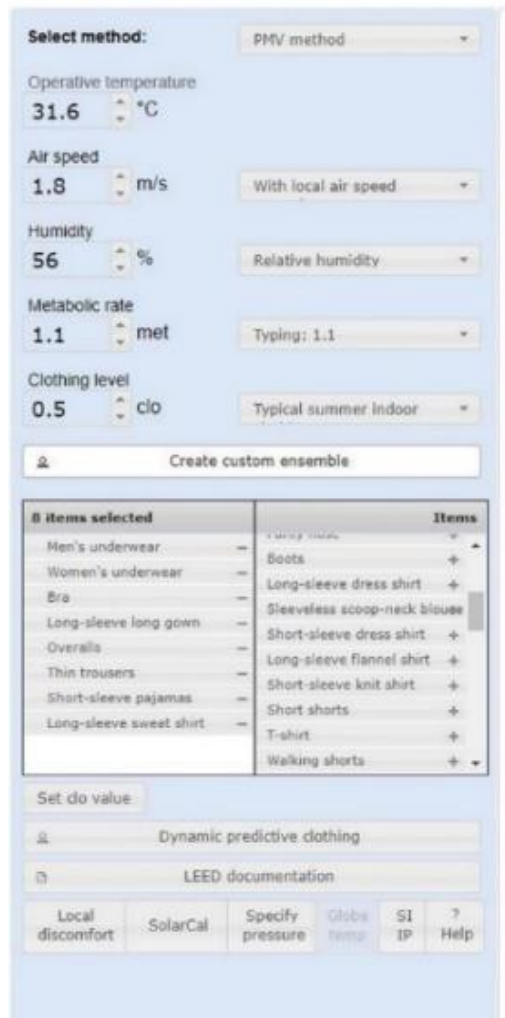

\begin{tabular}{l|l|l|l|l} 
ASHRAE-55 EN-15251 Compare Ranges & \\
\end{tabular}

$\begin{array}{ll}\times \text { Does not comply with ASHRAE standard 55-2017 } \\ \text { PMV with elevated air speed } & 0.69 \\ \text { PPD with elevated air speed } & 15 \% \\ \text { Sensantion } & \text { Sightly Warm } \\ \text { SET } & 27.4^{\circ} \mathrm{C} \\ \text { Dryoulb temperature at still air } & 27.3^{\circ} \mathrm{C} \\ \text { Coolingeffect } & 43^{\circ} \mathrm{C}\end{array}$

Peychrometric chart (operative temperature)

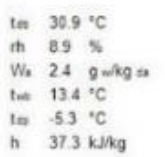

tis $-5.53^{\circ} \mathrm{C}$

h $37.3 \mathrm{~kJ} / \mathrm{kg}$

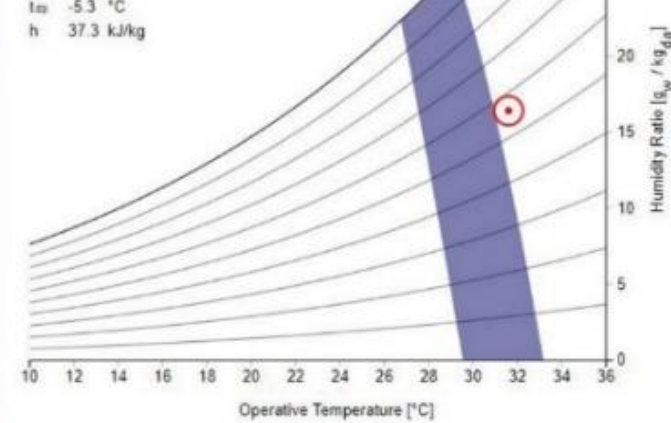

NOTE: in this perchromenic chan the abscises is the coerasve temperature

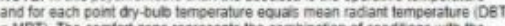

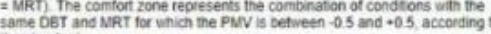
the obring

Fig. 8: Relative Thermal Comfort of Occupants in House C 
Fig. 8 shows the results calculated for House C. The Predicted Mean Vote (PMV) is slightly over the recommended value $(>+0.5)$ at 0.69 with $15 \%$ of Predicted Percentage of Dissatisfaction (PPD). This is slightly lower than house A. The occupants experienced a slightly warm sensation with a moderate Standard Effective Temperature (SET) at $27.4^{\circ} \mathrm{C}$. The cooling effect is $4.3^{\circ} \mathrm{C}$ and the Dry bulb Temperature at $27.3^{\circ} \mathrm{C}$, hence, the thermal comfort experienced by the occupants in house $\mathrm{C}$ is slightly lower than the comfort level experienced by the occupants in house $B$.
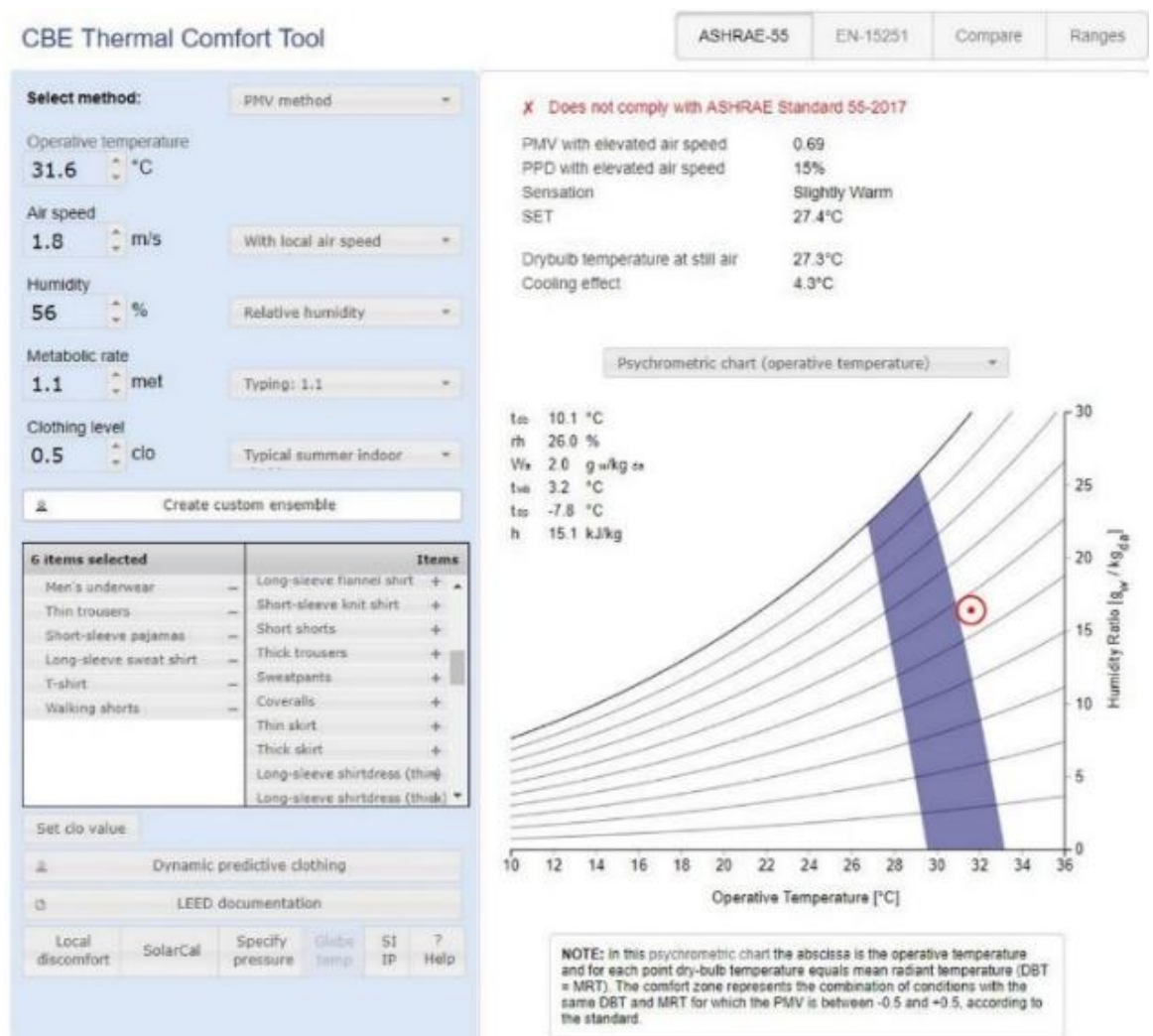

Fig. 9: Relative Thermal Comfort of Occupants in House D

Fig. 9 above shows the calculated thermal comfort based on ASHRAE Standard 55. It shows that house D does not comply with the standard $(>+0.5)$ as the house Predicted Mean Vote (PMV) is at 0.69 . The Predicted Percentage of Dissatisfaction (PPD) is moderate at $15 \%$. The occupants experienced a slightly warm sensation as the Standard Effective Temperature is $27.4^{\circ} \mathrm{C}$, slightly warmer than House B. The Dry Bulb Temperature at still air is higher than house $\mathrm{B}$, at $27.3^{\circ} \mathrm{C}$ with the cooling effect of $4.3^{\circ} \mathrm{C}$. These variables may affect the occupant's thermal comfort as the readings are higher than house $B$ and house $C$.

Table 2: Summary of Result

\begin{tabular}{|c|c|c|c|c|}
\hline SAMPLE HOUSE & A & B & C & D \\
\hline House Frontage & 24 Feet & 20 Feet & 24 Feet & 20 Feet \\
\hline WWR (\%) & $27.05 \%$ & $23.62 \%$ & $28.42 \%$ & $19.68 \%$ \\
\hline Relative Humidity & $68 \%$ & $56 \%$ & $56 \%$ & $56 \%$ \\
\hline Indoor Air Velocity & $1.8 \mathrm{~m} / \mathrm{s}$ & $1.8 \mathrm{~m} / \mathrm{s}$ & $1.8 \mathrm{~m} / \mathrm{s}$ & $1.8 \mathrm{~m} / \mathrm{s}$ \\
\hline Predicted Mean Vote (PMD) & 1.03 & 0.45 & 0.69 & 0.69 \\
\hline $\begin{array}{c}\text { Predicted Percentage of } \\
\text { Dissatisfied (PPD) }\end{array}$ & $27 \%$ & $9 \%$ & $15 \%$ & $15 \%$ \\
\hline $\begin{array}{c}\text { Standard Effective } \\
\text { Temperature (SET) }\end{array}$ & $28.9{ }^{\circ} \mathrm{C}$ & $26.6^{\circ} \mathrm{C}$ & $27.4{ }^{\circ} \mathrm{C}$ & $27.4{ }^{\circ} \mathrm{C}$ \\
\hline $\begin{array}{c}\text { Dry Bulb Temperature } \\
\text { (DBT) }\end{array}$ & $28.0^{\circ} \mathrm{C}$ & $26.6{ }^{\circ} \mathrm{C}$ & $27.3^{\circ} \mathrm{C}$ & $27.3^{\circ} \mathrm{C}$ \\
\hline
\end{tabular}




\subsection{Conclusion}

The study shows that an excellent thermal comfort in the living room can be achieved with lower WWR at the frontage wall of a terraced house. House B recorded the lowest mean temperature and higher humidity, which resulted in the highest thermal comfort measured. This compliance to ASHRAE Standard 55 enables the occupants to live comfortably compared to the other three houses. The lower WWR proved that there is a substantial heat reduction transmitted into the house through the wall openings (windows and doors). House A and House D show that they have higher WWR, hence, experiencing lower thermal comfort among the occupants.

The study also shows that the temperature and humidity level in the living rooms with bigger WWR had the lowest thermal comfort levels; hence, the occupants felt very uncomfortable. Besides the WWR, the window placements and the shading devices also play an essential role in reducing the sun exposure of the frontage wall. This passive design approach able to control heat transfer into the interior space, thus increase the indoor thermal comfort.

The thermal comfort study can be further expanded to include the influence of openable windows towards the effective natural ventilation. A comparative study between the visual comfort and the thermal comfort in an enclosed space will provide a useful guideline towards efficient window design.

\section{Acknowledgements}

The authors would like to thank UiTM for the infrastructure supports given.

\section{Paper Contribution to Related Field of Study}

The findings from the paper will benefit fellow researchers, designers, students, and those who involved directly and indirectly in the housing industry.

\section{References}

Abdul Rahman, M.A., Abdul Samad, M.H., Bahauddin, A., Ismail., M. R., (2009). Towards a Low-Energy Building Design for Tropical Malaysia. Penerbit Universiti Sains Malaysia, Penang, Malaysia.

ASHRAE 55-1992, (1992). Thermal Environment Conditions for Human Occupancy. ASHRAE Standards Atlanta, United States.

Baskaran, A., (2002). Dynamic wind testing of commercial roofing systems. National Research Council of Canada, Canada.

Jamaludin, N., Khamidi, M.F., Wahab, S.N.A., \& Klufallah, M.M., (2014). Indoor thermal environment in tropical climate residential building. In E3S Web of Conferences (Vol. 3, p. 01026). EDP Sciences.

Kubota, T. \& Toe D.H.C., (2010). Potential of passive cooling techniques for modern houses in tropical climate of Malaysia: Analysis of indoor thermal environment with various ventilation strategies. International Journal of Ventilation, 9(1), pp.11-23.

La Roche, P., Quirós, C., Bravo, G., González-Cruz, E.M. \& Machado, M., (2001). Keeping Cool: Principles to avoid Overheating in Buildings. PLEA, Passive and Low Energy Architecture International.

Liping, W., \& Hien, W.N., (2007). Applying natural ventilation for thermal comfort in residential buildings in Singapore. Architectural Science Review, 50(3), 224-233.

NAPIC (National Property Information Centre), (2008). Property Stock Report: Residential Property Stock Report Q3 2008. Valuation and Property Services Department, Ministry of Finance (electronic book on the Internet).

NAPIC (National Property Information Centre), (2018). Malaysian Property Market Report

Nugroho, A.M., Ahmad, M.H., \& Ossen, D.R., (2007). A preliminary study of thermal comfort in Malaysia' s single storey terraced houses. Journal of Asian Architecture and Building Engineering, 6(1), 175-182.

Pathirana, S., Rodrigo, A. \& Halwatura, R., (2019). Effect of building shape, orientation, window to wall ratios and zones on energy efficiency and thermal comfort of naturally ventilated houses in tropical climate. International Journal of Energy and Environmental Engineering, volume 10, pages107-120, Springer Link

Thomas, R. \& Garnham, T., (2007). Study on Efficiency of Passive Cooling Strategies on Thermal Comfort Attainment within Tropical Climate.

Edition 1st Edition. First Published 2007. eBook Published 13 September 2007. Pub. Iocation London. Imprint Taylor \& Francis Group

US Department of Energy, (2011). Attics: Ventilation. Energy Efficiency and Renewable Energy. Gill Martin, New Orleans, Lousiana.

Wyon, D.P., (1969). The effects of moderate heat stress on the mental performance of children. National Swedish Building Research, document no. 8.

Zain, Z.M., Taib, M.N., \& Baki, S.M.S., (2007). Hot and humid climate: prospect for thermal comfort in residential building. Desalination, 209(1-3), 261-268.

Zaki, W.R.M., Nawawi, A.H. \& Ahmad, S.S., (2010). Environmental Prospective of Passive Architecture Design Strategies in Terrace Houses. ASEAN Conference on Environment-Behaviour Studies, Riverside Majestic Hotel, Kuching, Sarawak, Malaysia, 7-8 July 2010 
Zr, D.L. \& Mochtar, S., (2013). Application of bioclimatic parameter as sustainability approach on multi-story building design in tropical area. The 3rd International Conference on Sustainable Future for Human Security SUSTAIN 2012. 